\title{
THE CLASSIFICATION OF MECHANICAL MODELS OF ROAD PAVEMENTS
}

\begin{abstract}
R. NAGÓRSKI ${ }^{1}$
A review of mechanical models of road pavements in the form of a proposal of classification of these models is presented. It is assumed an autonomy of the following elements of pavement model: the models of structural layers, the subgrade model, the interlayer bonding models, including bonding of pavement structure with its subgrade, the models of external impacts on pavement layers, including load of heavy traffic, the models of pavement environment impacts on structural layers' borders (lateral) and subgrade borders (including the lower one) according to the selected criteria such as structural criterion, material criterion (physical criterion), dimension criterion and model scope (purpose) criterion - in the frame of assumptions of the classical Newtonian deterministic mechanics. The presented attempt to classify mechanical models of road pavements supports to orientate the roadmen community within a scope of the mechanistic modelling of these structures.
\end{abstract}

Key words: road pavements, mechanistic modelling, classification of models, classification criteria

\section{INTRODUCTION}

The paper objective is a review of mechanical models of road pavements in the form of an attempt to classify these models with usage of a kit of several proposed criteria, while assuming an essential autonomy in developing of many individual elements of the road pavement models.

\footnotetext{
${ }^{1}$ Prof., DSc., PhD., Eng., Warsaw University of Technology, Faculty of Civil Engineering, ul. Lecha Kaczynskiego 16, 00-637 Warsaw, Poland; e-mail: r.nagorski@il.pw.edu.pl
} 
The mechanistic modelling, frequently in a combination with the experimental modelling (that uses certain terms from the mechanistic modelling), is now widely applied in a behaviour analysis of the road pavements, in particular in designing and diagnosing them. As an example one can name the frequent usage of the layered semi-spaces as these models. The layered semi-spaces are the classic continua comprised of the elastic or viscoelastic layers "connected" by the continuity displacement conditions (see e.g. [1]).

The classification of mechanical models of road pavements should include a classification of the following elements of road pavement models:

1) the models of load by heavy road traffic on upper road surface (roadway),

2) the models of pavement structural layers,

3) the models of pavement subgrade,

4) the models of interlayer bondings, including a connection between the pavement structure and its subgrade,

5) the models of external impacts on pavement layers (other than the road traffic),

6) the models of pavement environment (surroundings) impact on layers' borders (lateral) and subgrade's borders (including the lower one) - if applicable ${ }^{2}$.

In this paper these models have been considered within the assumptions of the classical Newtonian deterministic mechanics [2].

Theoretically, each layer, each interlayer bonding and each layer or subgrade border can be modelled independently (certainly, the external impact, too). The models of these elements can be combined respectively in the certain rational (correct, useful) sets, which define the specified models of the road pavement.

\footnotetext{
${ }^{2}$ For instance, the lateral borders do not exist in a pavement model in a form of the layered semi-space.
} 


\section{THE CRITERIA FOR CLASSIFICATION OF MECHANICAL MODELS OF ROAD PAVEMENTS}

We assume the following essential classification criteria of mechanical models of road pavements: structural criterion and material criterion. Furthermore, physical adequacy criterion, geometrical dimension criterion and scope (purpose) criterion are considered.

\subsection{THE MATERIAL CLASSIFICATION CRITERIA FOR ROAD PAVEMENT LAYERS. MODELS OF MATERIALS}

By the classification material criterion of pavement layer model (by the material model of layer) essentially can be understood:

a) a properly named constitutive relation, e.g. a relation that links in general the appropriately understood measures of internal interactions (e.g. stresses, when we treat the layer as a classical continuum [3]) and the respectively understood deformation measures (e.g. strains, when we treat the layer as a classical continuum), that defines the layer physical properties - e.g. a constitutive equation of elasticity [1] (then, it is told that the layer is with an elastic material)

b) and (if required) a properly named effort condition, i.e. a relation including in general the appropriately understood measures of the internal interactions (e.g. stresses, when we treat the layer as a classical continuum [3]) or the appropriately understood deformation measures (e.g. strains, when we treat the layer as a classical continuum [3]), that defines a layer state - e.g. a yield condition or a brittleness condition [1] (then it is told that the layer material is in the plastic state or a brittle state).

\subsection{THE STRUCTURAL CLASSIFICATION CRITERIA FOR ROAD PAVEMENT LAYERS. GEOMETRICAL MODELS}

By the classification structural criterion of pavement layer model (by the structural model of layer) we will essentially understand an appropriately named geometric structure of a distinguished layer configuration, named the reference configuration of this layer, i.e. a geometrical form in the Euclidean space of positions relative to the reference system, adopted by this configuration [4] (e.g. 
natural configuration), called the geometrical model of the layer ${ }^{3}$ that represents this layer (together with all its actual configurations), named also (in order to simplify) the pavement layer.

A structural criterion essentially prevails over material criterions, but frequently it is coupled with a material criterion (basically independent from a structural criterion, but also frequently connected with it).

\section{THE STRUCTURAL AND MATERIAL MODELS OF ROAD PAVEMENT LAYERS}

\subsection{THE CLASSICAL AND NON-CLASSICAL CONTINUOUS MODELS. NON-STANDARD MODELS}

While understanding by the layer deformation a reversible mapping (in the Euclidean space) of the layer reference configuration onto its actual configuration [1], we distinguish the following special structural models of pavement layer:
A. The classical continuous models - classical continua ${ }^{4}$ [3], [4].
B. The non-classical (continuous) models, including in particular:
B1) the multiphase media [5],
B2) the media with local additional deformations [6],
C. The non-standard models, including in particular:
C1) the non-continuous models [7],
C2) the multi-scale models [8],
C3) the fractal models [9].

\footnotetext{
${ }^{3}$ On the geometrical set, which is the geometrical model of a material object, are defined other quantities as well as relations that create a complete mechanical model of this object.

${ }^{4}$ named also the classical material continua.
} 


\subsection{THE CLASSICAL CONTINUOUS MODELS}

By the classical continuous model of pavement layer (by the pavement layer as a classical continuous material medium - classical continuum) is understood a space area featuring the shape of three-dimensional geometrical layer, which deformation is (in mathematical terms) a homeomorphism ${ }^{5}$ of $\mathrm{C}^{1}$ class $^{6}$ with the nonzero Jacobian. Each point of this area represents a material particle of the pavement layer, which has three degrees of freedom, defined by the vector components of particle displacement from its position in the reference configuration to its position to the current configuration of the layer [1].

With regard to the material criterion, the pavement layer as a continuum can be elastic, viscoelastic, plastic, elasto-plastic, visco-elasto-plastic etc. [11], [12].

\subsection{THE NON-CLASSICAL CONTINUOUS MODELS}

By the non-classical continuous model of pavement layer (by the pavement layer as a non-classical continuous material medium - non-classical continuum) is understood an area featuring the shape of geometrical layer, which deformation is homeomorphism of $\mathrm{C}^{1}$ class with the nonzero Jacobian. Each point of this area represents a material particle or more material particles of the pavement layer having $3+N$ degrees of freedom, defined by the vector components of displacement of this point (from its position in the reference configuration to its position in the current configuration of the layer) and by $N$ additional degrees of freedom.

In particular, there is multiphase material medium $(3+N=3 K ; K$-number of phases, usually $K=2$ or 3 ), when in each point of the pavement layer there is a particle of essential phase (matrix) and a particle of the other component phase (or more phases) [5]. Any particle of each phase has three degrees of freedom. For example, in the case of soil subgrade layer, the basic particles constitutes a porous soil skeleton and the additional particles - a liquid mixture of water and air [13].

Furthermore, we distinguish the material medium with local additional deformations, i.e. in each point of the pavement layer there is a particle which has $3+S$ degrees of freedom [6], i.e. 3 basic degrees of freedom (components of displacement vector from the position in reference configuration

\footnotetext{
${ }^{5}$ Homeomorphism is a reversible mapping of an set onto set of $\mathrm{C}$ class together with the inverse mapping

${ }^{6}$ i.e. differentiable with continuous derivatives
} 
to the position in current configuration of layer) and $S$ additional degrees of freedom, which usually represent the state variables defining local particle deformations other than the displacements (e.g. angles of a small rotation, homogenous linear strains or non-dilatational strains etc.) [14]. They may reflect a certain local medium microstructure [15] (e.g. its granularity).

\subsection{THE NON-STANDARD MODELS}

By the non-standard models of road pavement layers are understood the mechanical models, which due to the specified reasons are not included in the family of classical or non-classical continuous models described in par. 3.2 and par. 3.3 (see also par. 3.1).

Firstly, we distinguish a subfamily of the models of road pavement layers constituted by the discontinuous models. Generally, by the discontinuous model of layer we understand a system of material bodies or media ${ }^{7}$, which are characterised by any layer configuration or deformation discontinuity (as the whole $)^{8}$. In addition, we assume that this system is at least rather numerous, and its elements are characterised by a certain repeatability of a given property. As only in such case it is purposeful to create or use a certain (one common) model of all elements of pavement layer. So, the pavement layer featuring a single fracture (at most with a small number of fractures) are included into classical continuous modelling, in what is involved the classical fracture mechanics [16]. While a creation of the discontinuous model of layer can be aimed at, for instance, developing a model with

\section{fracture grid.}

The other type of the discontinuous models of pavement layer can be the discrete models. The discrete medium creates a system of the similar bodies with finite number of degrees of freedom (e.g. grains of mineral-asphalt mix or subgrade grains). In addition, using the discrete element method (DEM) [17] we obtain a real tool for analysing the pavement layer (e.g. [18], [19]). Due to a "material criterion" the interactions between the elements in the discrete medium can be of a similar type as in the classical continua, for example they can be of the elastic, viscous or visco-elastic nature ${ }^{9}$. Specifically, in the family of discontinuous models can be found the discrete-continuous models, which in a combination with the FEM (up to continuous part) and the DEM (up to discrete part) may effectively lead to the interesting results [20].

\footnotetext{
${ }^{7}$ By a material body we understand here a material object with the finite dimensions, small in respects of a crosswise and lengthwise of layer size (by a material medium we understand here an object, which features a significant or infinite crosswise or longwise size). Certainly, this division is ambiguous.

${ }^{8}$ More broadly - it fails to fulfil any condition that defines a continuum.

${ }^{9}$ An equivalent of the yield condition can be the Coulomb static friction condition [4]
} 
In the family of non-standard models of pavement layer can be distinguished the multi-scale models. Let us assume that in the layer structure can be distinguished a repeatable fragment (approximately), called a cell (e.g. an element of a system of small bodies creating the layer), which size in comparison with the layer characteristic size is appropriately small (the cell set is dense) and which reflects the layer microstructure. Next, let us assume that the layer deformation constitutes a sum of a primary (main) part, i.e. a continuous macro-deformation (macro-scale deformation) of this layer and additional local deformations of cells, i.e. micro-deformations of far smaller scales, but significant for the specified measures of this layer deformation. In this manner we develop a multiscale model of road pavement [21], [22]. When applying the concerned averaging method, called the homogenization procedure, from a multi-scale model we develop a continuous homogenized model [23], [24], in which the cell structure (layer micro-structure) is reflected too.

The fractal models constitute an interesting proposal of description of certain geometrical and material structures. Namely, it is assumed that in a layer structure can be distinguished an repeatable fragment, of which any small element presents, upon proper rescaling, the structure of whole fragment - we call it the fractal [25]. Here, it is of importance that, i.a., any fractal is described analytically by certain simple functions, and moreover its "geometrical" dimension (called the fractal dimension) can be non-integer number (e.g. the so called Mender sponge characterised by an "infinitely dense distribution of the free spaces" has the fractal dimension equal to $\ln 20 / \ln 3 \approx 2.7268<3$ [25]). This type of material media [9], [26] is connected with the differential and integral calculus with a usage of derivatives of $D$ order and $D$-muliple integrals, where $D$ is non-integer number [27].

The non-classical models, even though physically more adequate in terms of the geometrical and material structure than the classical models, are still characterised by a complexity of the model construction (linked to, for instance, a great number of the model parameters) and a relatively large computational complexity (these models are practically of a little use). The non-classical models find, for example, a certain use in the soil mechanics for modelling the pavement subgrades (e.g. [1], [13], [28], [29]). The non-standard models, intended as physically adequate (adopted to a physical structure of the pavement layer), are generally still not enough recognised and researched in qualitative and quantity terms, to be applied more broadly in practice. 


\section{THE $\alpha$ D DIMENSIONAL MODELS OF PAVEMENT LAYERS}

We use the following models for carrying out calculations and analyses as the utility models (classical, as well non-classical ones):

- the three-dimensional (3D, spatial) models [1], [30], [31], [32], e.g. for modelling the flexible pavement layers,

- or the two-dimensional (2D, surface, plate) models [1], [33], [34], [35], e.g. for modelling the structures of the rigid pavements,

- or the one-dimensional (1D, linear) models for modelling or carrying out analyses of the issues featuring a specific character [1], [36], [37] (e.g. for describing one-dimensional deformations of pavement layers).

In the two-dimensional model we apply an appropriate reduction of a layer configuration (mainly the natural configuration as the reference one) of the three-dimensional model to the twodimensional form (surface one), to which are assigned all quantities and relations specified for the two-dimensional model (in some cases it can be also recognised as the two-dimensional medium with an additional local deformation, e.g. certain rotation in the Hencky-Mindlin plate model [1], [34]). Similarly, in the one-dimensional model we apply a suitable reduction of a layer configuration of the three-dimensional model or a configuration of the two-dimensional model to an one-dimensional (linear) form, to which are assigned all quantities and relations specified for the one-dimensional model.

\section{THE MODELS OF INTERLAYER CONNECTIONS}

By an analogy to the pavement layer models are developed the interlayer connection models (models of bonding) of the neighboring pavement layers.

According to the structural criterion, a model of one connection can be developed respectively to a dimension criterion. It can be as follows:

- the three-dimensional (3D, spatial) model; a connection of two layers we treat as a thin layer; for modelling this layer it can be basically used any substantiated layer model, appropriately adopted to the physical and geometrical properties of the concerned connection (usually this layered "interface" is "connected" with the neighbouring layers by the deformation continuity conditions at borders of this interface and the neighbouring layers); 
- the two-dimensional (2D, surface) model [1], [38]; a connection is realised on the common border (e.g. a surface) of neighbouring layers that develops its (global model - e.g. full contact conditions, i.e. the deformation continuity conditions) or on the limited area at the borders of neighbouring layers (local model - e.g. full contact conditions) or on the system of small areas, outside which there is another connection type of the neighbouring layers (e.g. free contact conditions, i.e. the deformation continuity condition only in vertical direction to the common layer borders);

- one-dimensional (1D, linear) model; a connection is realised on a common line (in a form of curve arch or a section of straight line) or on a common line grid at the borders of neighbouring layers;

According to the material criterion (in the case of the surface and linear connection, rather called a physical criterion), the equivalents of the constitutive relations connect an interface deformation or deformation increments at the borders of neighbouring layers with the proper densities of the crosssectional interaction measures (forces) in the object constituting the connection of neighbouring layers. An equivalent of the yield condition (as a limiting stress condition) can be a Coulomb static friction condition.

The models of connection of the last pavement structural layer with its subgrade (with its spatial model) can be developed in the same manner in methodological terms as the interlayer connection models.

\section{THE MODELS OF LAYERS' ENVIRONMENT OF PAVEMENT STRUCTURE}

The model of the last pavement layer, that is a subgrade (usually a soil one) is developed similarly as for a layer situated above, according to the properties of real subgrade and the expectations towards its model [1], [39]. In the case of infinite spatial model, it is necessary to consider the disappearance in infinity of deformation along the thickness (in mathematical terms, the deformation as a transformation of layer reference configuration becomes identity).

If we are interested in the quantities linked to the subgrade specified only at its upper border (at the lower border of the pavement structure), so we can use the surface models (in order to determine the subgrade impact on the lower layer border of pavement structure). We can develop these models by analogy to the $2 \mathrm{D}$ interlayer connections (assuming that deformation of the layer beneath the subgrade is equal to identity). According to the "material criterion" the equivalents of the constitutive relations connect the appropriate measures of the "surface" subgrade deformations (e.g. deflections) with the proper densities of interaction measures (forces) in the object constituting the "surface" 
subgrade. These "constitutive relations" determine (jointly with other relations of the model) the appropriate densities of the subgrade reaction forces on the lower border of pavement structure.

The models of surface connections of structural layers with their surroundings (environment), e.g. models of support of the lateral layer border, can be developed analogically as interlayer connection models. For instance, it can be mentioned: the rigid layer border (e.g. the border supported by a concrete curb, the "computational" border far enough from a pavement area limited load), the free (non-loaded) layer border (e.g. an embankment slope), the pavement lateral layer border that interacts with the neighbouring soil and the others.

\section{THE MODELS OF EXTERNAL IMPACTS ON PAVEMENT LAYERS}

The models of external impacts on pavement layers (volumetrically distributed forces, temperature and transfer of heat, water and moisture, radiation and others) can be developed as the models of mechanical phenomena and non-mechanical phenomena independent of mechanical ones, or the models that connect the mechanical phenomena with the non-mechanical ones, generated by the mentioned factors (the models of vehicle impacts on pavements are discussed separately in the chapter 8). An example of this approach to the hydrological and mechanical phenomena can be a twophase medium (as an example of the non-classical medium), according to the Biot theory of consolidation[40] - with the porous solid phase (porous frame) developed from soil skeleton and liquid phase of water and air mixture, that is in the pores. If the mechanical phenomena are accompanied by a temperature impact [41], so we use the model of material medium with "additional degree of freedom" - a temperature in each point (generally, depending of time) - attaching the appropriately recorded relations based on thermodynamics [42]. If the coupling of non-mechanical and mechanical phenomena is weak, we use the models with non-mechanical phenomena independent from the mechanical ones, for instance the Fourier model of heat transfer in material medium (model of the temperature distribution in material medium) [43].

\section{THE MODELS OF PAVEMENT LOAD BY VEHICLE TRAFFIC}

A special shape is featured by the model of pavement load caused by vehicle traffic - the model formulated at the upper road border (called the pavement surface ${ }^{10}$ ) [44], [45]. This model is developed on the following four "levels".

\footnotetext{
${ }^{10}$ It can be not a surface in the strictly geometrical terms.
} 
On the level of tire contact of vehicle wheel with pavement surface we determine the contact area, called contact surface and the distribution of tire impact (pressure) of vehicle wheel on the pavement surface (wheel model together with tire can serve for this purpose); a resultant of the vertical interactions (perpendicular to the contact surface) is equal to a force of the wheel pressure onto the pavement surface, and a resultant of the tire tangents interactions is the friction force of wheel impact on the surface. Considering wheels' track of the vehicle as a mechanical system (featuring a finite number of the degrees of freedom) and taking into account the most significant static and dynamical effects of this vehicle we determine the static and dynamic system wheel pressure forces and friction forces as the model of impact of vehicle (vehicle axes) on pavement surface, which is the second level of pavement load model (at pavement surface) by vehicle.

A diversity of the design vehicle variants, in that the wheel tracks (axles tracks) and the distributions of the wheel pressure forces on the pavement surface comes to a certain standardisation of the heavy vehicles (which are only of significant importance for pavement behaviour in mechanical terms, especially for its durability), and even to a leading of the vehicle passage through road crosssection (as the basic periodical pavement load) to the specified multiplicity of passages of one standard axle with the standard pressure force on pavement surface (currently, $100 \mathrm{kN}$ or $115 \mathrm{kN}$ ), that constitutes the third level of modelling of pavement load by vehicles.

The pavement load by the vehicle traffic is determined by the number of standard axles acting on traffic lane of the pavement in the time unit (e.g. per $24 \mathrm{hrs}$.) or within the designed period (20 or 30 years) or in the actual operating period. This designed traffic is the fourth level model of pavement load by vehicles. The pavement should bear this load until the moment of conventional level of its degradation.

\section{THE SCOPE (PURPOSE) CRITERION OF PAVEMENT MODEL'S USE}

Among the "structural" models of road pavement it can be distinguished - with regard to a scope (purpose) of their use:

(i) the initial models (design models) - the models of designed pavement, correctly performed and commissioned to use (alternatively in the initial operating period, but still without any degradation);

(ii) the operational models - the models of state and behaviour of the pavement within the operating period, that usually mean the models of pavement degradation (as a result of many different factors), mainly the fatigue damage caused by cyclic load due to road traffic) [46] and the models pavement renewal (repair, renovation, reconstruction). 
The applied initial models of the pavement layers are mainly the continuous classical models (more seldom non-classical ones). Similarly, the renewal models of pavement layers (are usually the initial models in many aspects of a new pavement featuring the specified parameters upon the layers' renewal, however in practice it frequently happens that the renewal model refers only to one layer (upper) or all asphalt layers of the existing pavement, whereas the deformation of this pavement, partly damaged, can exert an impact on the shape of renewal model). In contrast, the degradation (damage) models should be basically the non-classical or non-standard models. The classical models are used in order to describe a degradation of the pavement layer in two cases:

a) when the degradation issue comes to the appropriate material model [47], [48], [49] (e.g. to the relations of the plasticity, viscosity or weakening),

b) when the single crack constitutes the degradation (e.g. lengthwise or crosswise) and its analysis is conducted within a frame of fracture mechanics [50] understood as an application of continuum mechanics.

With regard to the above an due to a key importance of the degradation issue for determining the pavement durability, the mechanical-empirical models are developed, used in practical terms, on the basis of which is determined the computational durability of road pavement due to the specified type of its degradation (measured by the number of standard axles which can pass through a crosssection of the road lane up to the stipulated level of assumed type of degradation) [51 ], [52], [53]. It has been found, on the basis of the experiments, that this durability depends on the stress or strain of the concerned structural or subgrade layer in the specified point, determined on the basis of the initial model (relatively simpler than the degradation model, usually the classical layered continuum featuring the elastic or viscoelastic layers).

\section{FINAL REMARKS}

The presented attempt to classify the mechanical models of road pavements facilitates to orientate the roadmen community within a scope of the mechanistic modelling of these structures according to the selected, most important from the author's point of view, criteria.

On the one hand, this attempt identifies the fields well developed within the above-mentioned scope, and on the other hand, the fields weakly fulfilled yet, which can indicate the development directions of the road pavement mechanics. It also supports a choice of the mechanical model of road 
pavement that is or physically adequate in respect of problem to be solved or sufficient for the utility purposes in engineering practice ${ }^{11}$.

Although, the proposed classification of pavement models is rather of general and broad nature, there are the models that fail to fall within its scope. For example, a probabilistic approach in the mechanistic modelling (in that, statistic and stochastic ones) has been omitted [54].

\section{REFERENCES}

1. R. Nagórski and others, "Mechanics of road pavements in outline" (in Polish), Scientific Publishers PWN (Wydawnictwo Naukowe PWN), Warsaw, 2014.

2. R. Nagorski, W.Szczesniak, "Theoretical mechanics" (in Polish), vol. 2, Publishing House of Warsaw University of Technology (Oficyna Wydawnicza Politechniki Warszawskiej), Warsaw, 1993.

3. Cz. Rymarz, "Continuum mechanics" (in Polish). Scientific Publishers PWN (Wydawnictwo Naukowe PWN), Warsaw 1993.

4. J. Ostrowska-Maciejewska, "Foundations of continuum mechanics" (in Polish), Scientific Publishers PWN (Wydawnictwo Naukowe PWN), Warsaw, 1982.

5. Cz. Eimer, "Theory of multiphase media" (in Polish), Theoretical and Applied Mechanics (Mechanika Teoretyczna i Stosowana) 10 (2) (1972) 243-258.

6. Cz. Woźniak, "Foundations of deformable bodies dynamics" (in Polish), Scientific Publishers PWN (Wydawnictwo Naukowe PWN), Warsaw 1969.

7. L. Wang, "Mechanics of Asphalt. Microstructure and Micromechanics", McGraw-Hill, New York 2011.

8. J. Fish, K. Shek, "Multiscale analysis of composite materials and structures", Composite Science and Technology 60 (2000) 2547-2556.

9. A. Carpinteri A., B. Chiaia, P. Cornetti, "A fractal theory for the mechanics of elastic materials", Materials Science and Engineering A365 (2004) 235-240.

10. S. Jemioło, A. Szwed, "Problems of statics of elastic layered half-space" (in Polish), Civil Engineering Faculty of Warsaw University of Technology, Warsaw, 2013.

11. P. Perzyna, "Termodynamics of non-elastic materials" (in Polish), Scienific-Technical Publishers WNT (Wydawnictwa Naukowo-Techniczne - WNT), Warsaw, 1978.

12. Y.R. Kim, "Modeling of Asphalt Concrete", ASCE Press - McGrow-Hill, New York, 2009

13. W. Derski, in: I. Kisiel (Ed.), Applied Mechanics, vol. VII, Mechanics of rocks and soils (in Polish), Scientific Publishers PWN (Wydawnictwo Naukowe PWN), Warsaw, 1982.

14. A.E. Green, R.S. Rivlin, "Multipolar continuum mechanics", Archive for Rational Mechanics and Analysis, 17 (2) (1964) 113-120.

15. A.E. Green, "Micro-materials and multipolar continuum mechanics", International Journal of Engineering Science, 3 (5) (1965), 533-542.

16. A. Neimitz, "Fracture mechanics" (in Polish), Scientific Publisher PWN (Wydawnictwo Naukowe PWN), Warsaw, 1998.

17. J.R. Williams, G. Hocking, G. Mustoe G, "The theoretical basis of the discrete element method", Numerical Methods in Engineering. Theory and Applications (1985), 897-906.

18. W. Bulttlar, Y. Zhanping, "Discrete element modeling of asphalt concrete: microfabric approach", Transportation Research Record. Journal of the Transportation Research Board 1757 (13) (2014).

19. C. O’Sullivan, "Particulate discrete element method. A Geomechanics perspective", Spon Press, London - New York, 2011

20. A. Munjiza, "The Combined Finite-Discrete Element Method", John Wiley \& Sons, London, 2004.

21. R. Talreja, "Multi-scale modeling in damage mechanics of composite materials", Journal of Materials Science 41 (20) (2006), 6800-6812.

22. E. Weinan, B. Engquist, Z.Y. Huang, "Heterogeneous multiscale method: a general methodology for multiscale modeling”, Physical Revue B 67 (092101) (2003).

These criteria are very often contradictory 
23. A.Bensoussan, J.L Lions, G. Papanicolau, "Asymptotic analysis for periodic structures", North-Holland, Amsterdam, 1978.

24. Duvaut G.: "Homogenization et materiaux composites", in: P. Ciarlet, M. Rouseau (Eds), Theoretical and Applied Mechanics, North-Holland, Amsterdam 1976, pp 194-278.

25. K.J. Falconer, "The Geometry of Fractal Sets", second ed., Cambridge University Press, Cambridge, 1990.

26. P,D. Panagiotopoulos, O.K. Panagouli, E.S. Mistakidis, "Fractal geometry and fractal material behaviour in solids and structures", Archive of Applied Mechanics, 63 (1993) 1-24.

27. S. G. Samko, A.A. Kibas, O.I. Marichev, "Fractional integrals and derivatives. Theory and applications", Gordon \& Breach, Amsterdam, 1993.

28. M.A. Biot; "General theory of three-dimensional consolidation", Journal of Applied Physics, 12 (1941)

29. I.I. Kandaurov, "Mechanics of granular media and its applications in construction" (in Russian), Gosstiechizdat, Moskva-Leningrad, 1977.

30. N. Odemark, "Investigations of the elastic properties of soils and design of pavements according to the theory of elasticity", Meddelande 77. Statens Vaginstitut, Stockolm, 1949, pp. 3-30.

31. Y.H. Huang, "Pavement Analysis and Design", Pearson - Prentice Hall, London, 2004

32. G. Martinček, "Dynamics of Pavement Structures", E \& FN SPON, Bratislava, 1994

33. H. M. Westergaard, "Theory of concrete pavement design", Proceedings of the Highway Research Board, Washington D.C., 1927.

34. G. Jemielita, in: Cz. Woźniak (Ed.), Applied Mechanics, vol. VIII, Mechanics of elastic plates and shells (in Polish), Scientific Publishers PWN (Wydawnictwo Naukowe PWN), Warsaw, 2001.

35. A. Szydlo, "Cement concrete road pavements", Polish Cement (Polski Cement), Cracow, 2004.

36. R. Nagorski, P. Wisniakowski, M. Nagorska, "One-dimensional consolidation of two-phase elastic layer" (in Polish), in: W. Szcześniak (Ed.), Polish-Ukrainian Transactions „Theoretical Foundation of Civil Engineering”, vol. 20, pp. 101-108, Publishing House of Warsaw University of Technology (Oficyna Wydawnicza Politechniki Warszawskiej), Warsaw, 2012.

37. A. Das, "Analysis of pavement structures", CRC Press, Taylor \& Francis Group, Boca Raton London New York, 2015.

38. J. Judycki, P. Jaskuła, A. Grądzka, "Theoretical modeling of interlayer bonding impact on the behavior of asphalt pavements" (in Polish) Report - stage 1, Cathedral of Road Engineering, Technical University of Gdansk, 2011.

39. G. Jemielita, W. Szczesniak, "Methods of subgrade modeling" (in Polish), Scientific Papers of Warsaw University of Technology (Prace Naukowe Politechniki Warszawskiej), series Construction (Budownictwo), 120 (1992)

40. M.A. Biot, "General theory of three-dimensional consolidation", Journal of Applied Physics, 12 (2) (1941) 155-164.

41. M. Graczyk, "Load-bearing capacity of multilayer pavements in domestic climatic conditions" (in Polish), series Studies and Reports (seria Studia i Materialy), vol. 63, Road and Bridge Research Institute (IBDiM), Warsaw, 2010.

42. K. Wilmanski, "Foundations of phenomenological thermodynamics" (in Polish), Scientific Publishers PWN (Wydawnictwo Naukowe PWN), Warsaw, 1974.

43. S. Wisniewski, "Heat exchange" (in Polish), Scienific-Technical Publishers - WNT (Wydawnictwa NaukowoTechniczne - WNT), Warsaw, 2000.

44. D. Cebon, "Handbook of vehicle-road interaction", Swetz \& Zeitlinger Publishers, Lisse,1999.

45. D. Godlewski, "Road Pavements" (in Polish), Publishing House of Warsaw University of Technology (Oficyna Wydawnicza Politechniki Warszawskiej), Warsaw, 2011.

46. K.P. George, A.S. Rajagopal, L.K. Lim, "Models for predicting pavement deterioration", Transportation Research Record 1215, Transportation Research Board, Washington DC, 1989

47. A. Drescher, J.Y. Kim, D.E. Newcomb, "Permanent Deformation in Asphalt Concrete", Journal of Materials in Civil Engineering 5 (1) (1993) 112-128.

48. Y. R. Kim, H. J. Lee, D. N. Little, "Fatigue Characterization of Asphalt Concrete Using Viscoelasticity and Continuum Damage Theory", Journal of the Association of Asphalt Paving Technologists 66 (1997) 520-569.

49. P. Kettil, B. Lenhof, K. Runesson, N.-E. Wiberg, "Simulation of inelastic deformation in road structures due to cyclic mechanical and thermal loads", Computers and Structures 85 (2007) 59-70.

50. F. M. Burdekin, D. E. W. Stone, "The crack opening displacement approach to fracture mechanics in yielding materials", Journal of Strain Analysis, 1 (1966) 145-153.

51. J. Piłat, P. Radziszewski, "Asphalt pavements" (in Polish), second ed., Transport and Communication Publishers WKŁ (Wydawnictwa Komunikacji i Lacznosci - WKL), Warsaw, 2007.

52. AASHTO Guide for the Design of Pavement Structures, American Association of State Highway and Transportation Officials, 1993

53. P. Radziszewski, "Fatigue durability modelling of modified mineral-asphalt composites" (in Polish), Scientific Transactions (Rozprawy Naukowe). vol. 45, Bialystok Technical University (Politechnika Białostocka), Bialystok 1997.

54. M.I. Darter, W.R. Hudson, "Probabilistic Design Concepts Applied to Flexible Pavement System Design”, Research Report 123-18, Center for Highway Research, The University of Texas, Austin, Texas, 1973 


\section{THE CLASSIFICATION OF MECHANICAL MODELS OF ROAD PAVEMENTS}

Key words: road pavements, mechanistic modelling, classification of models, classification criteria

\section{SUMMARY}

The paper contains a review of mechanical models of road pavements in the form of a proposal of classification of these models. It is assumed an autonomy of the following elements of the pavement model: the models of structural layers, the subgrade model, the interlayer bonding models, including bonding of pavement structure with its subgrade, models of external impacts on pavement layers, including the load of heavy traffic, models of pavement environment impacts on structural layers' borders (lateral) and subgrade borders (including the lower one) - according to the criteria selected by paper Author - in the frame of assumptions of the classical Newtonian deterministic mechanics. The above elements of pavement modelling can be combined respectively into certain rational (correct, useful) sets, which define the specified models of the whole road pavement.

It is assumed the following essential classification criteria of mechanical models of road pavements: structural criterion and material (physical) criterion. Furthermore, geometrical dimension criterion and scope (purpose) criterion are considered as the important ones.

Accordingly to that one can distinguish the well known models of materials of pavement layers: elastic, viscoelastic, elastoplastic, viscoelastoplastic etc. While according to the structural criterion it can be distinguished the following models of pavement layers: classical continuous models, non-classical continuous models (including in particular multiphase material media and material media with additional local degrees of freedom) and non-standard models (in that non-continuous models, multi-scale models and fractal models).

Due to the geometrical dimension criterion the models of pavement layers can be spatial (3D) and plane (plate, 2D), while according to the scope (purpose) criterion one can name the models: initial ones (for designed and new pavements) and operational ones (for pavement degradation and for pavement renewal).

Similarly to the layer models one can distinguish 3D or 2D models of pavement subgrade and interlayer connections as well as respectively classify the external factors acting on pavement.

The presented attempt to classify the mechanical models of road pavements facilitates to orientate the roadmen community within a scope of the mechanistic modelling of these structures according to the selected, most important from the Author's point of view, criteria. This attempt supports a choice of the mechanical model of road pavement that is or physically adequate in respect of problem to be solved or sufficient for the utility purposes in engineering practice.

Although, the proposed classification of pavement models is rather of general and broad nature, there are the models that fail to fall within its scope. For example, a probabilistic approach in the mechanistic modelling (in that, statistic and stochastic ones) has been omitted. 


\section{KLASYFIKACJA MODELI MECHANICZNYCH NAWIERZCHNI DROGOWYCH}

Slowa kluczowe: nawierzchnie drogowe, modelowanie mechanistyczne, klasyfikacja modeli, kryteria klasyfikacyjne

\section{STRESZCZENIE}

Praca zawiera przegląd modeli mechanicznych nawierzchni drogowych w formie propozycji klasyfikacji tych modeli. Założono autonomię w tworzeniu następujących elementów modelu nawierzchni: modele warstw konstrukcyjnych, model podłoża, modele połączeń (wiązań) międzywarstwowych, w tym konstrukcji nawierzchni z podłożem, modele oddziaływań zewnętrznych na warstwy nawierzchni, model obciążenia nawierzchni ruchem ciężkich pojazdów, modele oddziaływań otoczenia zewnętrznego nawierzchni na granice warstw konstrukcyjnych i na granice podłoża zgodnie z kryteriami klasyfikacyjnymi przyjętymi przez Autora - w ramach założeń mechaniki klasycznej i deterministycznej Newtona. Powyższe elementy modelowania nawierzchni mogą być odpowiednio zestawione w całościowe modele nawierzchni drogowej.

Założono następujące zasadnicze kryteria klasyfikacyjne modeli mechanicznych nawierzchni drogowych: kryterium strukturalne (struktury nawierzchni) i kryterium materiałowe (właściwości materiałowych). Ponadto przyjęto jako ważne kryterium wymiaru geometrycznego (modelu elementu nawierzchni) i kryterium zakresu (celu) stosowania modelu.

Zgodnie z powyższym wyróżniono następujące (znane) modele materiałów warstw nawierzchni: sprężyste, lepko-sprężyste, sprężysto-plastyczne, lepko-plastyczne, sprężysto-lepko-plastyczne itd. Natomiast zgodnie z kryterium strukturalnym wyróżniono następujące modele warstw nawierzchni: klasyczne modele ciągłe, nieklasyczne modele ciągłe (w tym ośrodki wielofazowe i ośrodki z dodatkowymi lokalnymi stopniami swobody) oraz modele niestandardowe (w tym modele nieciągłe, modele wielkoskalowe i modele fraktalne).

Według kryterium wymiaru geometrycznego modele warstw nawierzchni mogą być przestrzenne (3D) i płaskie (2D, płytowe), natomiast zgodnie z kryterium zakresu (celu) stosowania modeli wymieniono modele początkowe (dla nawierzchni zaprojektowanych i nowo wybudowanych) i modele eksploatacyjne (dla nawierzchni degradowanych i odnowionych).

Podobnie do modeli warstw konstrukcyjnych można wyróżnić modele 3D i 2D podłoża oraz połączeń międzywarstwowych, a także odpowiednio sklasyfikować modele czynników zewnętrznych działających na nawierzchnie.

Przedstawiona próba klasyfikacji (elementów) modeli mechanicznych nawierzchni drogowych ułatwia środowisku drogowców orientować się w zakresie mechanistycznego modelowania tych obiektów zgodnie z wybranymi, zdaniem Autora najważniejszymi, kryteriami klasyfikacyjnymi. Próba ta wspomaga wybór mechanicznego modelu nawierzchni drogowej fizycznie adekwatnego do rozwiązywanego problemu lub modelu wystarczająco użytecznego do celów praktyki inżynierskiej.

Chociaż proponowana klasyfikacja modeli nawierzchni jest ogólna i szeroka, to są modele, które się w tej klasyfikacji nie mieszczą. Przykładowo, pominięto w niej podejście probabilistyczne (w tym statystyczne i stochastyczne) w modelowaniu mechanistycznym nawierzchni. 